\title{
【ミニシンポジウム報告】
}

高齢者の食事支援サービスとフードチェーン

一やさいくる活動の実例—

(株)日本栄養給食協会 入江 成子

\section{Meal Support for Elderly People and Foodchain}

\author{
Shigeko IRIE \\ Nihon Eiyou Kyuusyoku Kyoukai Co.Ltd
}

\section{1.はしじめに}

(株)日本栄養給食協会は平成元年に設立された、 給食受託事業を主とする企業である。栃木県宇都 宮市を中心に病院、クリニック、老人福祉施設、 社会福祉施設、学校、幼稚園、保育園など約 180 件の給食事業を受託している。また、宅配食サー ビス、地産地消こだわりの弁当、スポーツ選手へ の弁当製造、郊外型ベーカリー店の運営なども手 がけている企業である。

\section{2. 高齢者の食事支援サービスの現状}

本会は、平成 6 年より宅配治療食事業を開始し た。このサービスは退院後の食事療養に不安を感 じている患者様からの要望に応える形での開始と なった事業である。

減塩食、糖尿病食、人工透析食などの治療食か ら、高齢者向けの一般食へと内容は拡大し、現在 では、1 日に約200食の製造、宅配を行っている。

また、平成13年度より宇都宮市の、平成15年度 より佐野市の高齢者食の自立支援事業の認定を受 け、行政との連携の下、在宅療養者のサポートを 行っている。行政指導の中には、安否確認を行う ことも盛り达まれており、単なる配食にとどまら ない利用者の生活スタイルに入り込んだ地域密着 型のケータリングサービスとして展開している。 近年は、大手メーカーの安価弁当が進出してきて おり、ニーズは、低コスト傾向がより明確になり
つつある。

\section{3. 未来環境食循環システム (やさいくる活動)}

給食からは、毎日たくさんの食品残椬が廃棄物 として発生する。食品廃棄物の処理問題について 長年、問題視していた。本会では、食品残椬を液 肥化し、「捨てる」から「活かす」を実現する食 ベ物の循環に成功した。

本会では、現在、地球がまわるように食べ物も つながり、環になり、新たなものを生み出す「未 来環境食循環システム」に取り組んでいる。

また地産地消の推進、地域ブランドの確立など にも注力している。ものづくりと併せて、「伝え る」「残す」「守る」という、人間としての使命感も 育んでいきたいと考えている。

\section{未来環境 食循環システム}

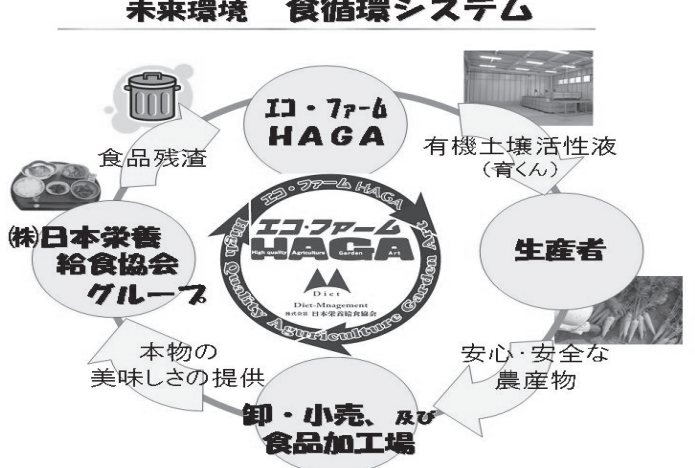

図 1 未来環境食循環システムの概念図 


\section{4.「エコ・ファームHAGA」と「ごろごろ畑」}

本会では、食品残椬を24時間で液肥化する工場 「エコ・ファームHAGA」を平成 22 年 1 月 5 日に スタートさせ、同年 6 月には、農業生産法人株式 会社「育くん（そだつくん）ファーム」を設立し、 農産物生産を始めた。

土潩活性液を「育（そだつ）くん」と名づけ、 「育くん」を $10 \mathrm{a}$ あたり $1 \mathrm{t}$ 以上使用し、減農薬 で栽培した畑を「ごろごろ畑」、ごろごろ畑で育 った野菜は「ごろごろ畑野菜」としてブランド化 を試みている。そしてほかの一般流通品とは区別 し、自社のブランド野菜として、給食、宅配食、 ベーカリー店などで使用している。

新鮮で旨みが濃いとされる「ごろごろ畑野菜」 は、栄養価も高く、契食者からの評価も高い。高 齢者の食事支援サービスの中でも使用されている。

\section{5. グループ内の多様化}

給食受託事業を基幹としているため、食材卸業 も一体となり連携業務を行っている。グループ内 物流システムが整っていることも大きな特徴であ り、循環型システムを整備できた理由でもある。 給食受託事業以外の分野としても、ケータリン グフードサービス、石葖パン工房県内 3 店舗運営、 宇都宮餃子製造、地産地消弁当製造等、新鮮な安 心安全野菜として「ごろごろ畑野菜」を活用する 分野が拡大しつつある。

また、給食受託先や食育イベント等での「ごろ ごろ畑野菜」の販売を行い、グループ内の活動を 生産者も一緒になりアピールしている。

以上のような一連の取り組みが社会的にも評価 され、平成23年第 3 回地産地消給食等メニューコ ンテストにおいて「美適食彩ヘルシー弁当」が農 林水産省生産局長賞を受賞した。

また、平成23年度版食育白書に、本事例が紹介 された。栃木県内においては、平成 22 年第 3 回マ ロニエECO事業所「フードマイレージ削減部門 特別賞」を受賞した。地方の民間の給食会社とし

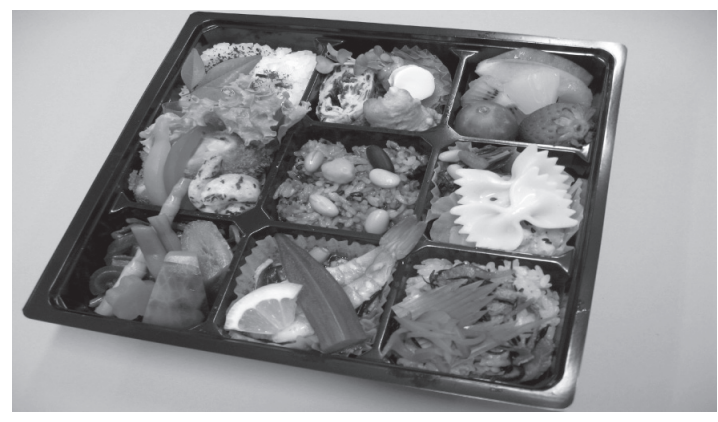

図2 受賞商品〈美適食彩ヘルシー弁当〉

ての取り組みとしては前例がないとして、全国か ら注目されつつある。

\section{6 次化の推進}

グループ 5 社内の中で、生産 $\rightarrow$ 加工 $\rightarrow$ 消費が可 能であり、また、真空加工が可能な工場を併設し ていることにより、ごろごろ畑ブランドを使用し た付加価值の高いオリジナル真空加工商品製造の 強化をすすめている。

セントラルキッチンの能力を向上させ、年間を 通じて安価良品な商品がお客様に提供出来るよう、 バリューチェーンの構築を推進している。

\section{7. おわりに}

東日本大震災後、栃木県内においても放射能污 染の問題は大きい。本会の栽培計画、生産、売り 上げに大きな影響を及ぼしている。

地産地消に対する考え方も様々ではあるが、今 後も地産地消を推進し、安心・安全な農産物での 商品開発を進めていく方針である。

未来環境型食循環システム (やさいくる活動) を通し、日本、栃木、宇都宮の抱えている農業や 食料問題についても、生産から消費まで担う企業 として向き合っていきたいと考えている。

力強い土づくりを行い、「美味しい、昔の味が する」生命力のある農産物づくりと流通体制の整 備を推し進め、地域密着型のフードシステムをさ らに構築していきたい。 